\title{
Phase transitions in cortical dynamics explain improved information processing under attention
}

\author{
Nergis Tomen", Udo Ernst \\ From Twenty Second Annual Computational Neuroscience Meeting: CNS*2013 \\ Paris, France. 13-18 July 2013
}

A major aspect of cortical information processing is its rapid adaptation to the actual behavioral demands. Highly representative for such processes is selective visual attention, which has been shown to improve performance in visual perception (see e.g. [1]). The neural mechanisms supporting these effects have been investigated in electrophysiological studies: Besides firing rate modulations and tuning curve changes in visual cortical neurons, they revealed a strong increase of oscillations in the gamma frequency band $(35-90 \mathrm{~Hz})$ [2]. These findings indicate that gamma oscillations might play an important role in optimizing information processing under attention, but their functional role is currently not yet understood.

The dynamics of cortical networks exhibit certain properties that have been suggested to be linked to optimization of information processing: criticality and balance. Experimental studies indicate that cortical networks operate near a 'critical' state in which scale-free avalanches of spike events occur [3], generating neural patterns which are 'rich' in structure [4]. These critical states are indicators of a phase transition from an asynchronous regime of activity in the network towards a synchronous regime. Furthermore, it has been observed that excitatory and inhibitory synaptic currents to cortical neurons are balanced [5], which allows cells to detect rapid changes in the stimulus and provides an explanation for the high variability of neural activity.

Here we explore the relationship between the phase transition towards synchrony, balance, and enhanced stimulus representation in a simple network of integrateand-fire neurons driven by an external stimulus. By increasing the efficacy of recurrent couplings, attention improves spontaneous synchronization and renders activation patterns for different stimuli more distinct. We compare this result to experimental evidence demonstrating that object representation in cortical local field potentials (LFPs) is improved in macaque monkeys under attention [6], and find a near-perfect match between model and LFP data.

By analyzing the LFPs and avalanche statistics of the simulated network activity, we show that the enhancement of discriminability of LFP power spectra is strongly correlated with phase transitions towards synchrony. More importantly, our results indicate that networks operating near phase transitions reside in a regime where a dramatic enhancement of stimulus representation may require only fine modulations of synaptic strengths. Taken together, our study implies that attention drives the cortex towards a critical state, inducing oscillatory activity and hereby improving the discriminability of different stimuli represented in the corresponding network activity. Furthermore, our framework suggests a novel role for synchronization in cortical information processing.

Published: 8 July 2013

\section{References}

1. Posner MI, Snyder CR, Davidson BJ: Attention and the detection of signals. Journal of Experimental Psychology: General 1980, 109:160-174.

2. Fries $P$, Reynolds $\mathrm{JH}$, Rorie $A \mathrm{E}$, Desimone R: Modulation of oscillatory neuronal synchronization by selective visual attention. Science 2001, 291:1560-1563.

3. Beggs JM, Plenz D: Neuronal avalanches in neocortical circuits. The Journal of Neuroscience 2003, 23:11167-11177.

4. Haldeman C, Beggs JM: Critical branching captures activity in living neural networks and maximizes the number of metastable states. Physical Review Letters 2005, 94:058101.

5. Okun M, Lampl I: Instantaneous correlation of excitation and inhibition during ongoing and sensory-evoked activities. Nature Neuroscience 2008, 11:535-537.

\footnotetext{
* Correspondence: nergis@neuro.uni-bremen.de

Institute for Theoretical Physics, University of Bremen, 28359 Bremen, Germany
}

(c) 2013 Tomen and Ernst; licensee BioMed Central Ltd. This is an Open Access article distributed under the terms of the Creative Commons Attribution License (http://creativecommons.org/licenses/by/2.0), which permits unrestricted use, distribution, and reproduction in any medium, provided the original work is properly cited. 
6. Rotermund D, Taylor K, Ernst UA, Kreiter AK, Pawelzik KR: Attention improves object representation in visual cortical field potentials. The Journal of Neuroscience 2009, 29:10120-10130.

doi:10.1186/1471-2202-14-S1-P126

Cite this article as: Tomen and Ernst: Phase transitions in cortical dynamics explain improved information processing under attention. BMC Neuroscience 2013 14(Suppl 1):P126.

Submit your next manuscript to BioMed Central and take full advantage of:

- Convenient online submission

- Thorough peer review

- No space constraints or color figure charges

- Immediate publication on acceptance

- Inclusion in PubMed, CAS, Scopus and Google Scholar

- Research which is freely available for redistribution

Submit your manuscript at www.biomedcentral.com/submit
Ciomed Central 